\title{
Anonychia congenita in different generations of a single Saudi family
}

Deemah M. Bin Nooh, MD, Tarek M. Hegazi, MD, Iqbal A. Bukhari, PhD.

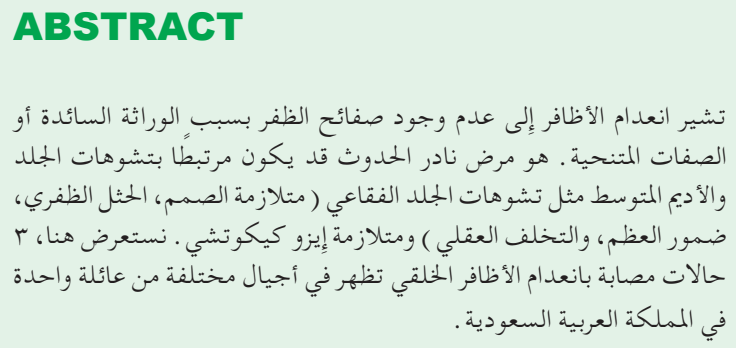

Anonychia refers to the absence of nail plates owing to an autosomal dominant or recessive inheritance. Congenital anonychia is a rare condition that may be associated with other ectodermal or mesodermal malformations like epidermolysis bullosa, (deafness, onychodystrophy, osteodystrophy, and mental retardation) syndrome and Iso-Kikuchi syndrome. Here, we report 3 cases with anonychia congenita appearing in different generations of a single family in Kingdom of Saudi Arabia.

Keywords: Anonychia, nail disorders, autosomal dominant, genetic disorder, mutation, case report

Saudi Med J 2020; Vol. 41 (2): 195-198 doi: $10.15537 /$ smj.2020.2.24884

From the College of Medicine (Bin Nooh); from the Department of Radiology (Hegazi); from the Dermatology Department (Bukhari), Imam Abdulrahman Bin Faisal University and King Fahd Hospital of the University, Dammam, Kingdom of Saudi Arabia.

Received 25th October 2019. Accepted 26th December 2019.

Address correspondence and reprint request to: Dr. Iqbal A. Bukhari, Dermatology Department, College of Medicine, Imam Abdulrahman Bin Faisal University, Dammam, Kingdom of Saudi Arabia. E-mail:ibukhari@iau.edu.sa

ORCID ID: orcid.org/0000-0001-8127-1168

Disclosure. Authors have no conflict of interests, and the work was not supported or funded by any drug company.
Congenital anonychia is a rare condition characterized by the absence of multiple nails or the whole fingernails, toenails, or both, since birth. It may occur as an isolated abnormality or as part of a syndrome or condition. The most common types of anonychia are acquired anonychia and congenital syndromic anonychia, which usually linked to other anomalies compared to the congenital nonsyndromic type. ${ }^{1}$ The skin in the place of the missing nails is normal and the nail bed and nail matrix or fold are intact in all fingers and toes. ${ }^{2}$ Complete anonychia generally follows an autosomal recessive pattern and has been allocated to chromosome 20p13 with a mutation in the R-Spondin 4 (RSPO4) gene, and frizzled class receptor 6 (FZD6). ${ }^{3,4}$

Here, we report 3 cases of complete anonychia congenita running in different generations of a single family which has never been reported in Kingdom of Saudi Arabia (KSA).

This study aims to plan and conduct genetic analysis to detect RSPO4 gene mutations with family history consultation for these patients

Case Report. All of the 3 cases belong to one generation from a single large family of Arabic origin from KSA, with other 4 affected individuals of different generations (Figure 1).

Patient one. A 19-year-old Saudi male presented with complete absence of all fingernails and toenails since birth. He was born by normal vaginal delivery, full term with normal weight in an uneventful pregnancy. He had normal developmental milestones with no associated physical abnormalities. The parents are first degree relatives and healthy, without any congenital anomalies. No other congenital disorder was known in the family (Figure 2).

Patient 2. An 8-year-old Saudi female presented with complete absence of all fingernails and toenails since birth. The mother was on $100 \mathrm{mg}$ thyroxine during her pregnancy due to hypothyroidism. The patient had normal developmental milestones with no associated physical abnormalities. The parents are first 


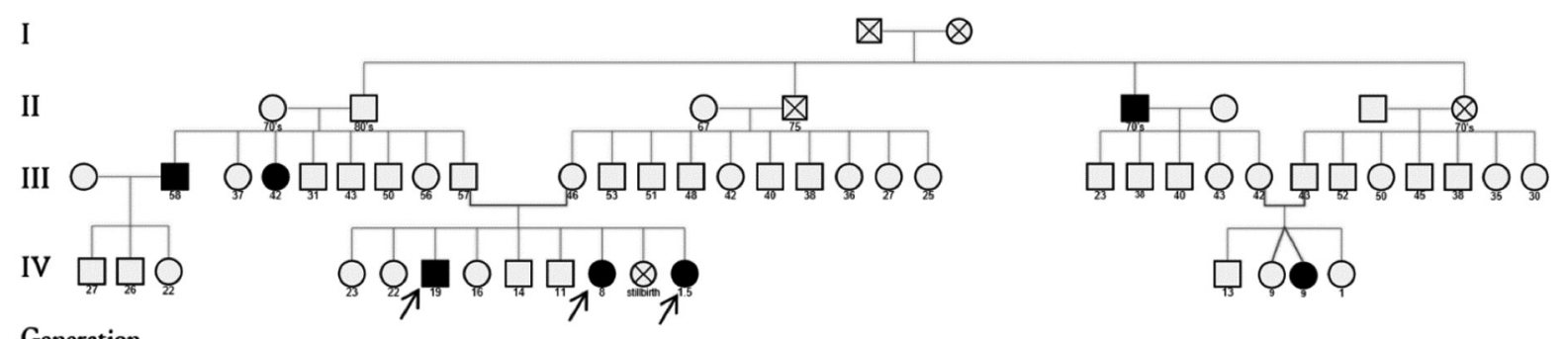

Figure 1 - Pedigree of the family with simple congenital anonychia, showing the 7 affected members belonging to different generations. Arrows represent the studied patients.

degree relatives and healthy, without any congenital anomalies. No other congenital disorder was known in the family (Figure 3).

Patient 3. An 18-month-old female infant presented with complete absence of all nails in hands and feet since birth. She was a full-term baby with normal weight in an uneventful pregnancy. The mother was on 200 mg thyroxine due to hypothyroidism. The patient had normal developmental milestones with no associated physical abnormalities. The parents are first degree relatives and healthy, without any congenital anomalies. No other congenital disorder was known in the famil? (Figure 4).

Clinical findings. Upon examination, all the 3 patients exhibited absence of nail plates in hands and feet with normal nail beds, nail folds, and phalanges. The skin of the fingers and toes was normal. Systemic examination included teeth, hair, and mucous membranes and was normal. Sensory and motor functions of hands and feet were intact.

Diagnostic assessment. Plain $\mathrm{x}$-ray examination of the hands and feet of all the patients revealed normal appearance of the bones (Figure $1 \& 2$ ). Rest of the skeletal survey was also normal. Visual acuity and pure tone audiometry were also normal. Based on all the observations, the 3 patients were diagnosed as anonychia congenita patients. As shown in the timeline table (Table 1).

Discussion. Anonychia congenita, an inherited non-syndromic nail disorder which is characterized by isolated abnormalities of the nails. There are 10 different types of "Nail disorder, Nonsyndromic Congenital". ${ }^{4}$ Anonychia congenita is characterized by complete absence or severe hypoplasia of all nails of the fingers and toes with no associated physical or mental abnormality.
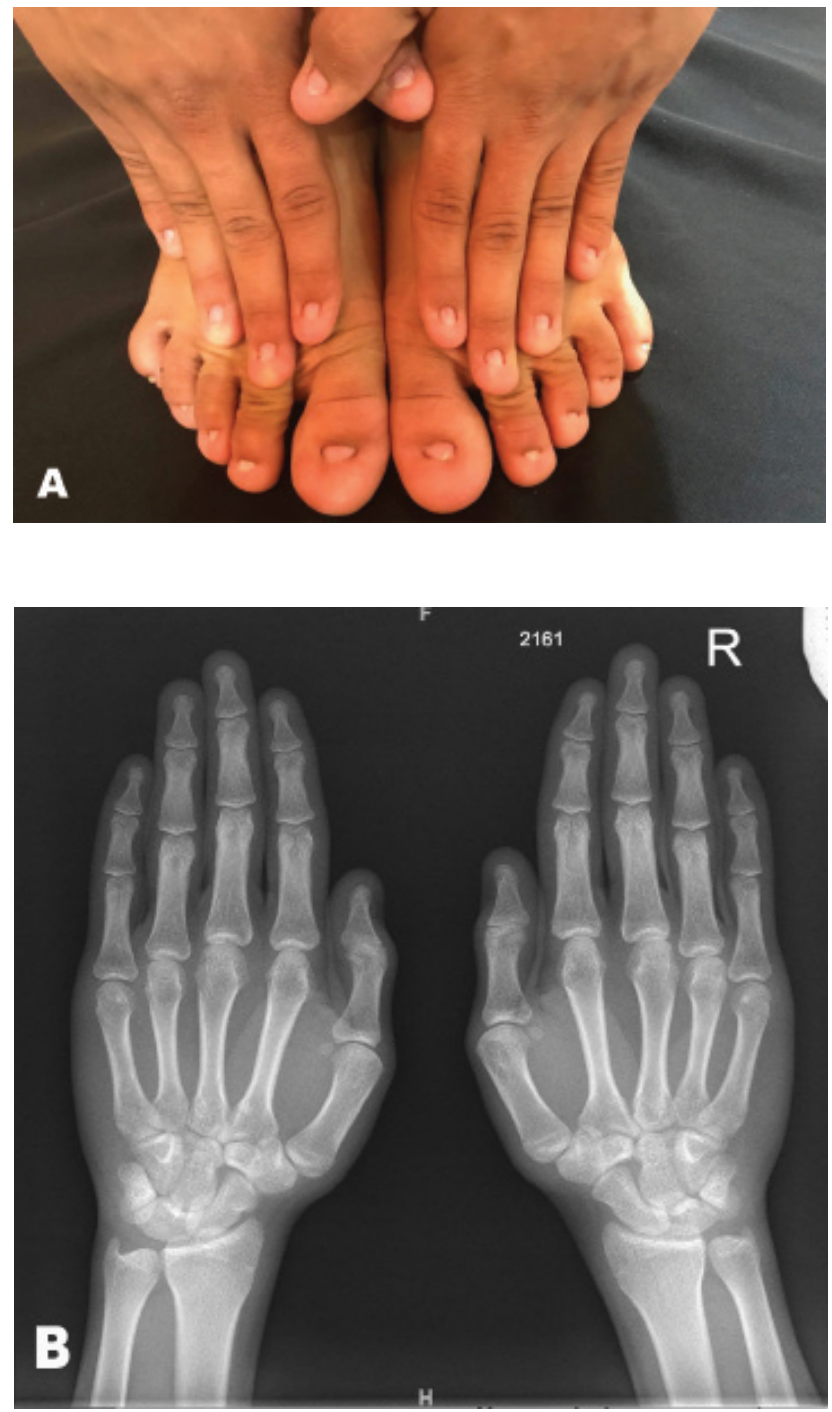

Figure 2 - A) Total anonychia of all nails of fingers and toes of patient one. B) Normal bone appearance of both hands as seen in the $\mathrm{x}$-ray report. 

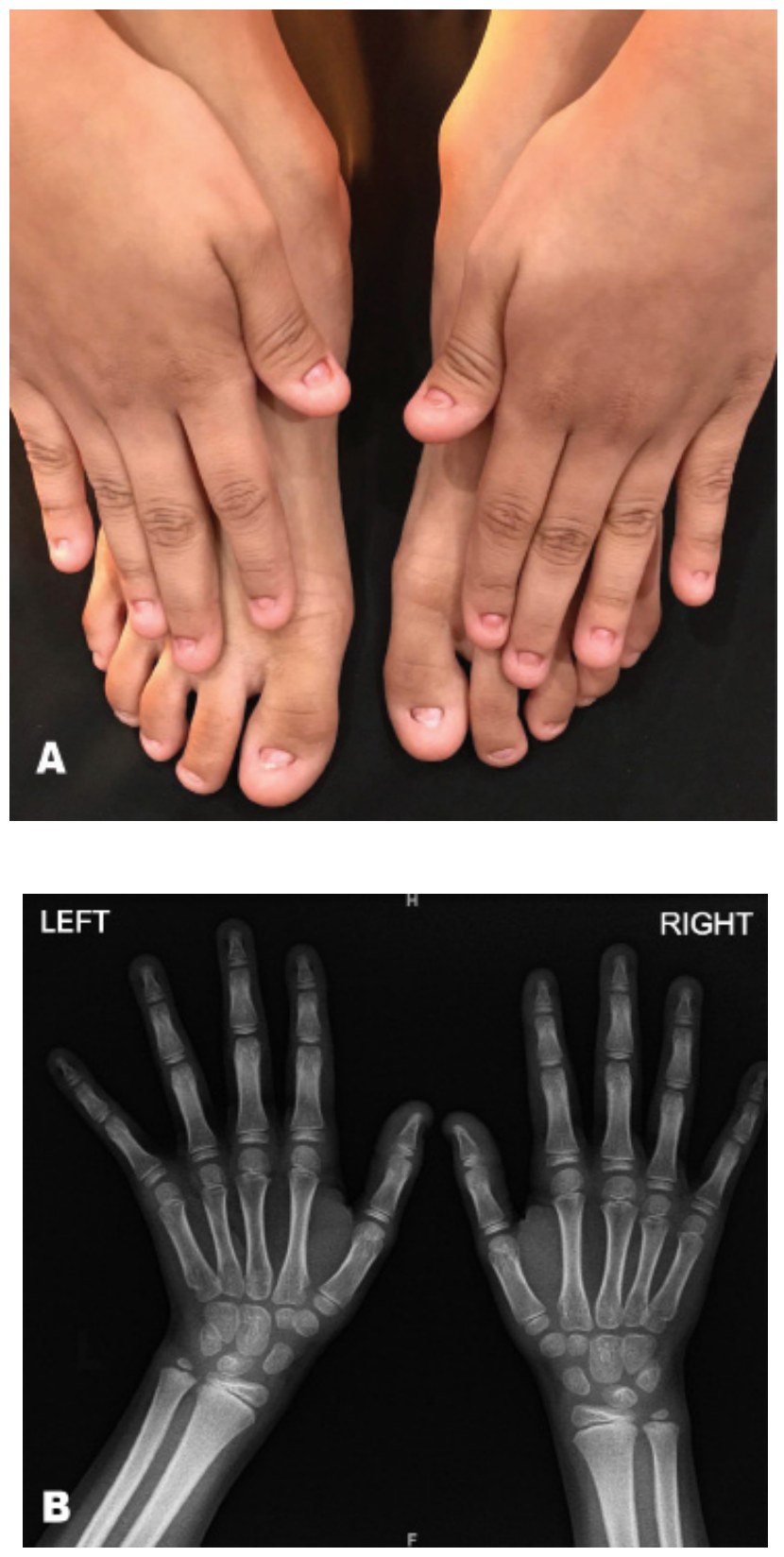

Figure 3 - X-ray showing the A) total anonychia of all nails of fingers and toes of patient, and B) Normal bone appearance of both hands.

It is of an autosomal recessive mode of inheritance with RSPO4 gene mutation mapped to chromosome 20p13 with frameshift splice site and missense mutations in exon 2. ${ }^{3,5,6}$ Congenital anonychia may be associated with hypoplastic or missing underlying phalanges and patella, teeth abnormalities, microcephaly, curved digits, single transverse palmar crease, bizarre

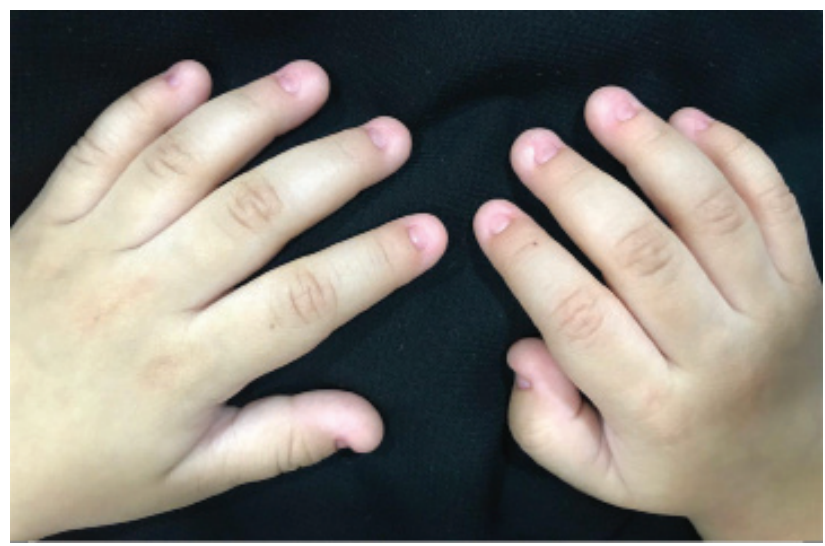

Figure 4 - Total anonychia of all fingernails of patient 3.

Table 1 - Timeline of 3 causes with anonychia congenita.

\begin{tabular}{|c|c|c|c|}
\hline Dates & \multicolumn{3}{|c|}{ Relevant past medical history and interventions } \\
\hline Oct. 2, 2018 & \multicolumn{3}{|c|}{$\begin{array}{l}3 \text { siblings presented with complete absence of all } \\
\text { fingernails and toenails since birth. They was born by } \\
\text { normal vaginal delivery, full term with normal weight in } \\
\text { an uneventful pregnancy. They had normal developmental } \\
\text { milestones with no associated physical abnormalities. } \\
\text { Their parents are first degree relatives and healthy, without } \\
\text { any congenital anomalies. Family history revealed other } 4 \\
\text { affected individuals of different generations. } \\
\text { No other congenital disorder was known in the family } \\
\text { Upon examination, all the } 3 \text { patients exhibited absence } \\
\text { of nail plates in hands and feet with normal nail beds, } \\
\text { nail folds, and phalanges. Systemic examination was } \\
\text { unremarkable. }\end{array}$} \\
\hline Dates & $\begin{array}{l}\text { Summaries from } \\
\text { initial and follow- } \\
\text { up visits }\end{array}$ & $\begin{array}{l}\text { Diagnostic testing } \\
\text { (including dates) }\end{array}$ & Interventions \\
\hline Oct. 22,2018 & $\begin{array}{l}\text { Plain x-ray was } \\
\text { ordered for hands } \\
\text { and feet for all } \\
\text { patients. }\end{array}$ & $\begin{array}{l}\text { Plain x-ray } \\
\text { examination of the } \\
\text { hands and feet of all } \\
\text { the patients revealed } \\
\text { normal appearance } \\
\text { of the bones }\end{array}$ & $\begin{array}{l}\text { No } \\
\text { intervention } \\
\text { was taken at } \\
\text { this point. }\end{array}$ \\
\hline Nov. 1, 2018 & $\begin{array}{l}\text { On follow up: } \\
\text { skeletal survey, } \\
\text { visual acuity } \\
\text { and pure tone } \\
\text { audiometry was } \\
\text { carried out. }\end{array}$ & $\begin{array}{l}\text { Skeletal survey was } \\
\text { normal. Visual } \\
\text { acuity and pure } \\
\text { tone audiometry } \\
\text { were also normal of } \\
\text { all the patients. }\end{array}$ & $\begin{array}{l}\text { Patients } \\
\text { were referred } \\
\text { for genetic } \\
\text { analysis and } \\
\text { family history } \\
\text { consultation }\end{array}$ \\
\hline
\end{tabular}

flexural pigmentation, hair abnormalities, and mental retardation with sensorineural deafness. ${ }^{7}$ However, a rare form exists which is without any associated bony defect as in our patients. Besides, congenital anonychia may be associated with other ectodermal or mesodermal deformities including deafness, onychodystrophy, osteodystrophy, and mental retardation syndrome, 
epidermolysis bullosa, and Iso-Kikuchi syndrome. Drugs such as carbamazepine, phenytoin, warfarin, morphine, and trimethadione taken by the mother during the first and second trimesters of pregnancy can lead to nail deformities. ${ }^{8}$

The literature search has identified only 74 reports of anonychia congenita until 2017, most of which have Pakistani roots. ${ }^{9}$ Nevertheless, there are few other reported cases in Turkey, Russia, Great Britain, United States of America, Holland, Brazil, Iran, India, Kazakhstan, Lebanon, Kuwait, Finland, and in Germany. ${ }^{3,6,10-13}$ In KSA, it has been reported in a single patient and in 2 members of the same generation in another family. ${ }^{10,14}$ The 3 patients in this study had complete anonychia as an isolated and asymptomatic condition which marks them as one of the rare reported cases in Saudi Arabia, as its running in different generations of a single family.

Therefore, it is essential to screen those cases for visual, auditory, skeletal, dermatological and neurological disorders. Unfortunately, there is no medical or surgical treatment available, though artificial nails can be considered.

In conclusion, this is a case report of anonychia congenita affecting 3 members of one generation in an extended family with multiple affected generations of Arabic origin in KSA. Genetic analysis will be employed to confirm the diagnosis.

Acknowledgment. The authors gratefully acknowledge Editage (www.editage.com) for English language editing.

\section{References}

1. Yadalla HKK, Nitya R, Sujatha C. A rare case of isolated congenital complete simple anonychia. Int J Health Allied Scien 2012; 1: 32-33.

2. Rigopoulos D, Petropoulou H, Nikolopoulou M, Kalogirou $\mathrm{O}$, Katsambas A. Total congenital anonychia in two children of the same family. J Eur Acad Dermatol Venereol 2006; 20 : 894-896.
3. Blaydon D, Ishii Y, O’Toole E, Unsworth H, Teh M, Rüschendorf F, et al. The gene encoding R-spondin 4 (RSPO4), a secreted protein implicated in Wnt signaling, is mutated in inherited anonychia. Nature Genet 2006; 38: 1245-1247.

4. Khan S, Basit S, Habib R, Kamal A, Muhammad N, Ahmad W. Genetics of human isolated hereditary nail disorders. $\mathrm{Br} J$ Dermatol 2015; 173: 922-929.

5. Brüchle N, Frank J, Frank V, Senderek J, Akar A, Koc E, et al. RSPO4 is the major gene in autosomal-recessive anonychia and mutations cluster in the furin-like cysteine-rich domains of the wnt signaling ligand $\mathrm{r}$-spondin 4. J Invest Dermatol 2008; 128: 791-796.

6. Bergmann C, Senderek J, Anhuf D, Thiel C, Ekici A, PobleteGutiérrez $\mathrm{P}$, et al. Mutations in the gene encoding the wntsignaling component r-spondin 4 (RSPO4) cause autosomal recessive anonychia. Am J Hum Genet 2006; 79: 1105-1109.

7. Ayaz SB, Mujahid TA, Matee S, Ayaz F. Congenital anonychia totalis: A rare occurrence in a Pakistani family. J Postgrad Med Inst 2017; 31: 88-92.

8. Mian A, Jorwal P. Congenital non-syndromic anonychia totalis with acroosteolysis. BMJ Case Rep 2017; pii: bcr-2017222743.

9. Ishii Y, Wajid M, Bazzi H, Fantauzzo KA, Barber AG, Blaydon DC, et al. Mutations in R-Spondin 4 (RSPO4) Underlie Inherited Anonychia. J Invest Dermatol 2007; 128: 867-870.

10. Al Aboud K, Al Aboud D. Autosomal recessive total congenital anonychia, in a Saudi family. Our Dermatol Online 2013; 4: 496-497.

11. Gharaeinejad K, Rafiei R, Yousefkhani L, Rafiee B, Sheikhpour A. Simple congenital anonychia in an Iranian family. Our Dermatol Online 2017; 8: 186-188.

12. Khalil S, Hayashi R, Daou L, Staiteieh S, Abbas O, Bergqvist $\mathrm{C}$, et al. A novel mutation in theRSPO4gene in a patient with autosomal recessive anonychia. Clin Exp Dermatol 2017; 42: 313-315.

13. Hsu Ck, Romano MT, Nanda A, Rashidghamat E, Lee JY, Huang HY, et al. Congenital anonychia and uncombable hair syndrome: coinheritance of homozygous mutations in RSPO4 and PADI3. J Invest Dermatol 2017; 137: 1176-1179.

14. Al Hawsawi K, Al Aboud K, Alfadley A, Al Aboud D: Anonychia congenita totalis: a case report and review of the literature. Int J Dermatol 2002; 41: 397-399. 